\title{
Hispanic Laborer Dies From Fall Off Roof
}

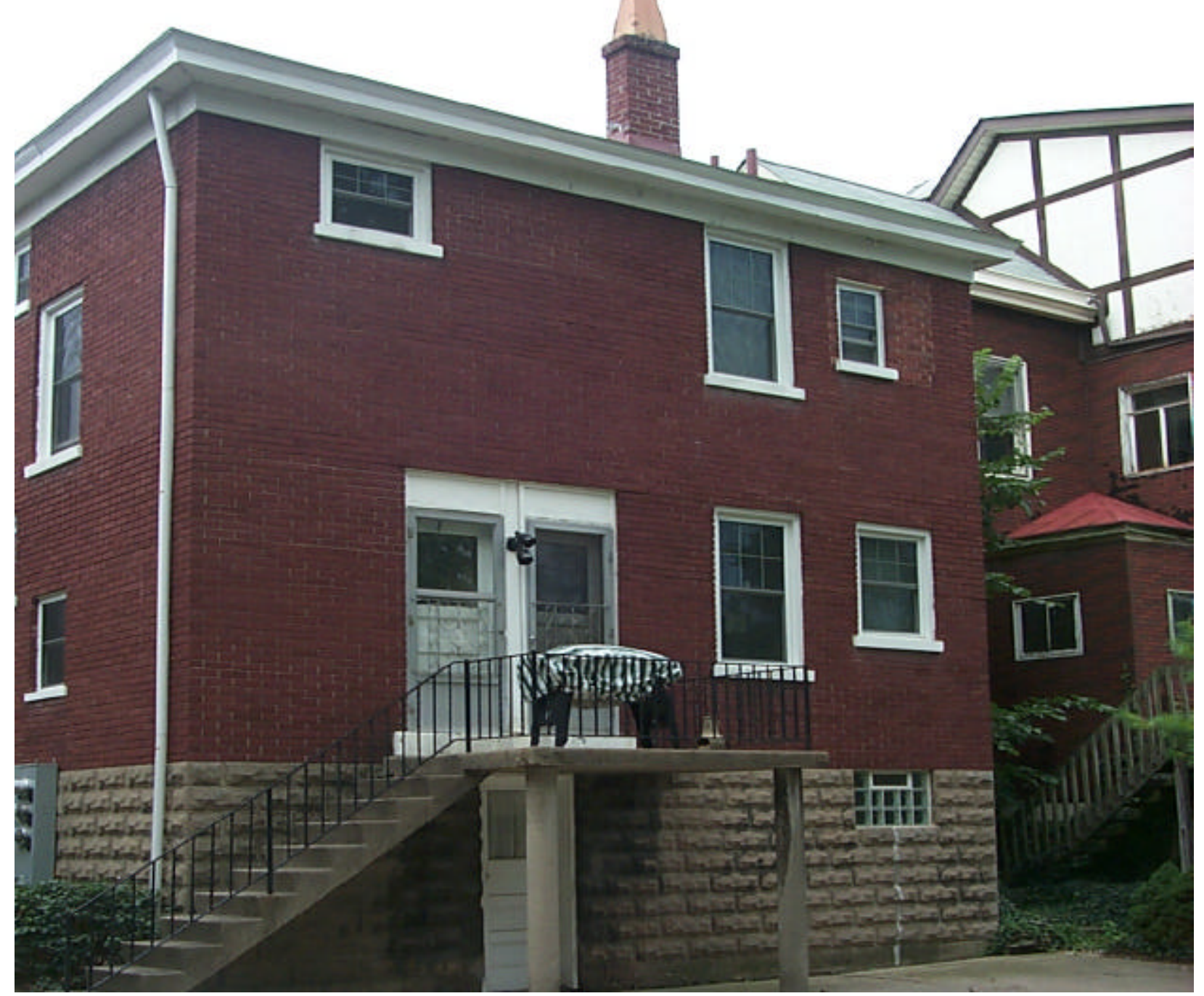

Roof from which Hispanic woman fell.

\section{Incident Number:}

Kentucky Fatality Assessment and Control Evaluation Progran Kentucky Injury Prevention and Research Center 333 Waller Avenue

Suite 202

Lexington, Kentucky 40504

Phone: 859-323-2981

Fax: 859-257-3909

www.kiprc.uky.edu

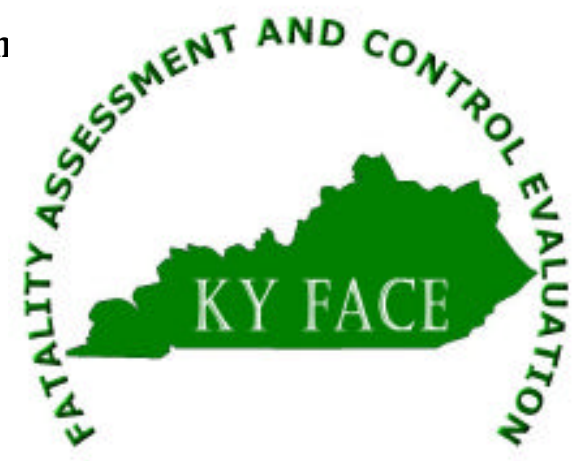




\section{Kentucky Fatality Assessment and Control Evaluation (FACE) Program Incident Number: 03KY017 \\ Release Date: $\quad$ October 21, 2003 \\ Subject: $\quad$ Hispanic Laborer Dies From Fall Off Roof}

\section{Summary}

On March 3, 2003, a 22-year-old Hispanic female laborer (decedent) died when she fell from a roof. She had been working on the roof with her brother, who was a sub-contractor for a local roofing company. The work crew consisted of two brothers and the decedent. Two days prior to the incident, the decedent had worked for her brother cleaning and organizing materials on the ground at another location. It was the decedent's first day on this job site. It is unknown whether or not the decedent had worked on other roofing jobs. Her job was to organize materials and hand her brothers tools. Just before falling, she had handed one brother a hammer. Neither brother saw her fall, but they heard the crash of guttering falling and found their sister on the ground below. She was not wearing any personal fall protection nor was a fall protection system in place at the time of the incident. She was transported to a local hospital where the coroner pronounced her dead "due to multiple blunt force injuries, due to fall from a great height".

To prevent future occurrences of similar incidents, the following recommendations have been made:

\section{Recommendations}

Recommendation No. 1: Contractors hiring subcontractors should take responsibility for ensuring through contract language the subcontractors have an adequate safety program and understand and follow general safety practices and applicable Occupational Safety and Health Standards.

Recommendation No. 2: Both roofing employers and subcontractors should provide comprehensive fall protection training and personal fall protection for their employees that is site specific.

Recommendation No. 3: Employers should ensure workers receive safety training in their native language and be informed of hazardous and unsafe working conditions.

\section{Background}

The Kentucky Fatality Assessment and Control Evaluation program was notified by a government agency on March 7, 2003, of an occupational fatality that occurred March 5, 2003, involving a Hispanic woman. The local coroner was contacted and interviewed at length via telephone and the owner of the contracting roofing company was contacted. A site visit was made on August 27, 2003, when the investigating police officer was interviewed and the building photographed. 
A locally owned roofing company subcontracted roofing jobs to a number of subcontractors. One of the subcontractors used was owned and operated by a Hispanic male who had been subcontracting his labor with the roofing company for approximately 1.5 years. The subcontractor hired other Hispanics to work for him including his brother and his sister. On the day of the incident, one of the subcontractor's brothers and his sister were working with him. It is unknown if roofing safety procedures were discussed. The brothers spoke broken English. Whether or not the sister spoke any English is unknown.

The decedent had been in the United States for two or three months and had been employed elsewhere prior to being employed temporarily by her brother. She had only been employed by her brother one or two days prior to the day of incident. She worked for him while searching for other employment.

\section{Investigation}

On the morning of March 3, 2003, a Hispanic subcontractor was replacing gutters on a building for a roofing contractor. There were three people on the job site: the subcontractor, his brother and his sister.

The trio was replacing box guttering on a building which housed offices and apartments. There were two levels of roofing; one roof was one story lower than the second roof. Access to the roofs was gained by a ladder from the ground to the lower roof and a ladder from the lower roof level to the higher roof level (see Photograph A). Scaffolding or other fall protection systems were not utilized at this job site at the time the decedent fell.

This job process first entailes removing the existing box guttering on the building by loosening and removing the flanges used to secure the box guttering to the roof edge. Then, new box guttering is assembled on the ground with new flanges attached to hold the new boxes together. Afterward, this assembly is transported by ladders to the roof. There, the subcontractors would begin installing the guttering by attaching the flanges of the box guttering to the edge of the roof. This type of guttering is to be installed from the middle of the edge of the roof to the end of the roof line. Each side slopes to drain pipes on the corners; creating a peak in the middle of the guttering that should overlap in the middle by two inches.

March $3^{\text {rd }}$ was the decedent's first day on this job site. Having cleaned and organized materials for the past day or two, she was working as a laborer retrieving equipment, tools and acting as a gofer for her brothers. At approximately 3:55 pm, one brother asked her to retrieve a hammer for him, which she did. After passing the hammer to her brother, the decedent proceeded to the other side of the roof. The brothers heard the box guttering break away from the roof and their sister fall to the ground.

Upon hearing the guttering split and fall, the brothers went to the other side of the roof to find their sister had fallen to the ground. The subcontractor ran a block to the police station and pounded on the window until an officer came outside and spoke with him. In broken English, the subcontractor communicated that his sister had fallen from a roof and they needed help. The 
police officer called emergency medical services (EMS) to the scene. Police officers and EMS arrived at the scene within a few minutes of being contacted. Cardio-pulmonary resuscitation was administered to the sister as she was transported to a nearby hospital. At the hospital, the coroner pronounced her dead.

\section{Cause of Death}

The coroner cited the cause of death "due to multiple blunt force injuries, due to fall from a great height" (the distance is unknown).

\section{Recommendations and Discussions}

Recommendation No. 1: Contractors hiring subcontractors should take responsibility for ensuring through contract language the subcontractors have an adequate safety program and understand and follow general safety practices and applicable Occupational Safety and Health Standards.

Many subcontractors (typically with less than 10 employees) are hired which do not have safety programs specific for the work to be performed. Contractors should ensure subcontractors are aware of relevant standards and should require subcontractors to follow all existing Occupational Safety and Health work safety standards as they themselves follow.

The Kentucky Occupational Safety and Health Standards for the Construction Industry Subpart M - 1926.500-503, states that workers exposed to heights of six feet or more (some exceptions apply) must be protected from hazards of falling. According to the U.S. Department of Labor, the most frequently cited serious violations of fall protection is "failure to protect workers from falls of 6 feet or more off unprotected sides or edges, e.g. floors and roofs (1926.5019b)(1); (b)(10); and (b)(11))".

There were several methods the roofers could have used to work safely while working on the guttering. One method would have been to use approved scaffolding with appropriate side railings. Another method would have been to use body harnesses tied off to anchors attached to studs on the roof.

Recommendation No. 2: Both roofing employers and subcontractors should provide comprehensive fall protection training and personal fall protection equipment for their employees that is site specific.

Each work site should be analyzed for hazards specific to that work site. Identified hazards should be communicated to the employees working at the job site, as should means to control these hazards.

Recommendation No. 3: Employers should ensure workers receive safety training in their native language and be informed of hazardous and unsafe working conditions. 
Employers should ensure that all workers are properly trained for jobs they are to perform. When a language barrier exists, the employer should identify the languages spoken by their workers. Safety programs should be designed to accommodate a multi-language work force at the literacy level appropriate for the work force. A competent interpreter should be available to explain workers rights to safety protection, safe work practices including how to conduct a work place hazard assessment and how to avoid the identified hazards.

Employers should work with local ethnic leaders and local community groups, such as churches or other organizations and organize training courses for non-English speaking persons pertinent to the type of work required for that local area. These courses should include basic safety training and an explanation that all workers (legal or illegal) in the United States are protected from working in unsafe working conditions.

\section{Keywords}

Fall

Hispanic

Personal fall protection

Roofing

Safety training

Subcontractor

\section{References}

Kentucky Occupational Safety and Health Standards for the Construction Industry, 29 CFR Part 1926

http://www.osha.gov/Region7/fallprotection?192sub_m_overview

KY FACE the FACTS Haz Alert, Vol 2, Issue 1, July 2003

\section{Acknowledgements}

Local Coroner

Local Police Detective

Roofing contractor

The Kentucky Fatality Assessment \& Control Evaluation Program (FACE) is funded by a grant from the Centers for Disease Control and the National Institute of Safety and Health. FACE's purpose is to aid in the research and prevention of occupational fatalities by evaluating events leading to, during, and after a work related fatality. Recommendations are made to aid employers and employees to have a safer work environment. Current focuses of the program are occupational fatalities involving: construction, machinery, immigrant workers (particularly Hispanics) and youth.

For more information about FACE and KIPRC, please visit our website at: www.kiprc.uky.edu. 
Both brothers were here

Location where

sister fell from

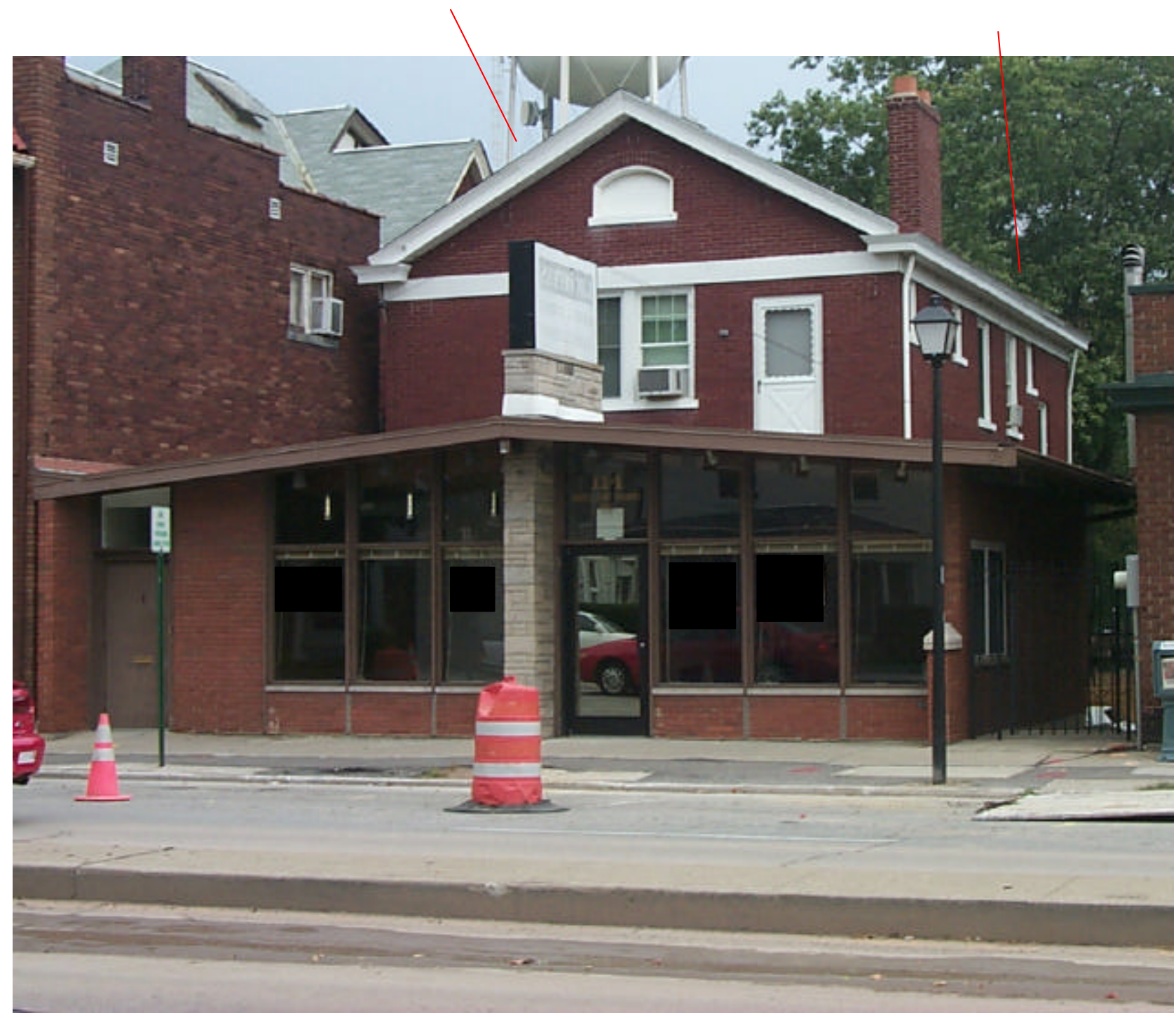

Front of building where incident occurred. The two brothers were working on the North side of the roof. The decedent fell from the right side back corner of the roof. North is to the left. One ladder was placed on the sidewalk to the lower level roof; the second ladder was placed on the lower level roof to the higher roof.

Photograph A 


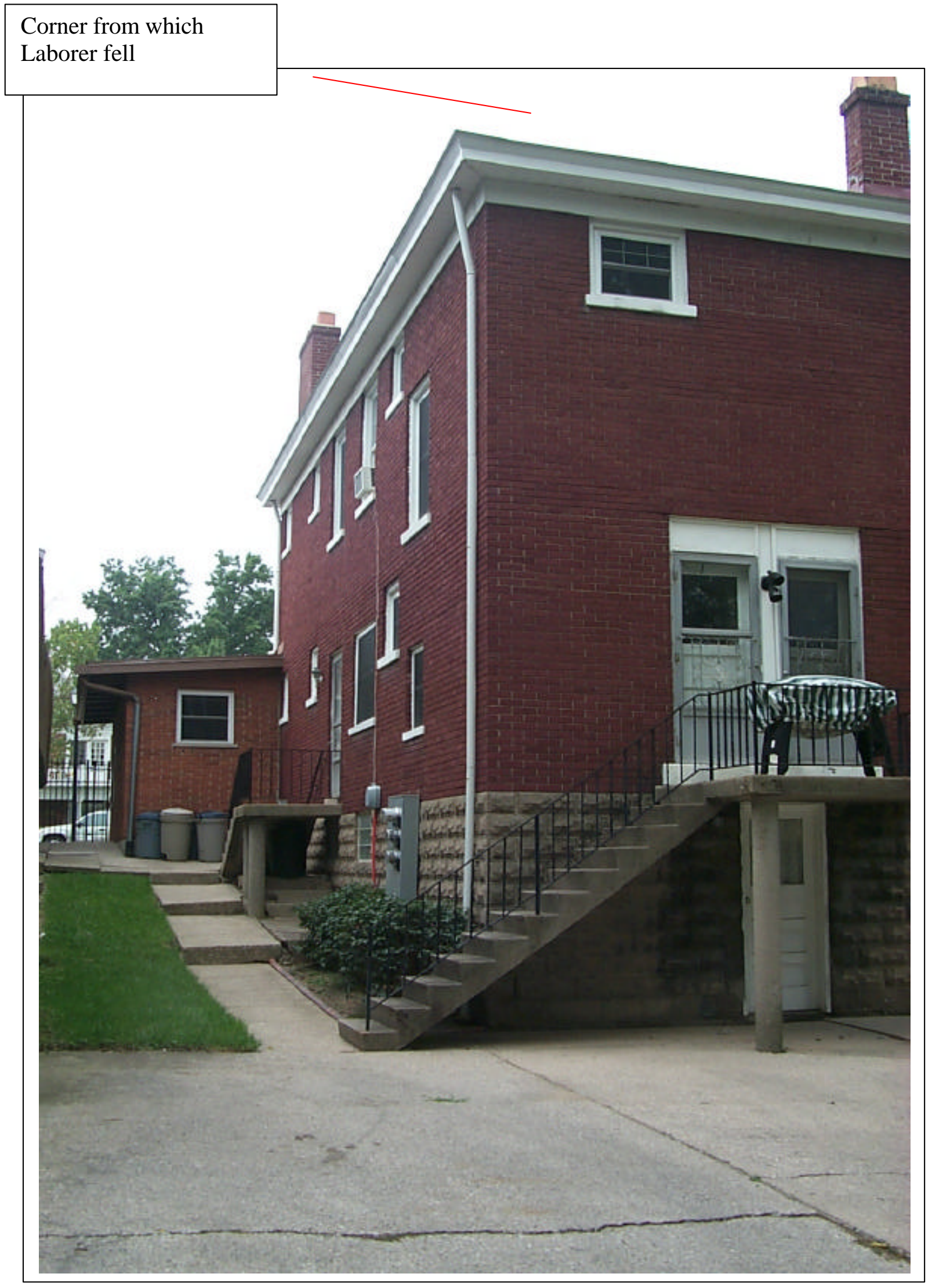

Photograph B 


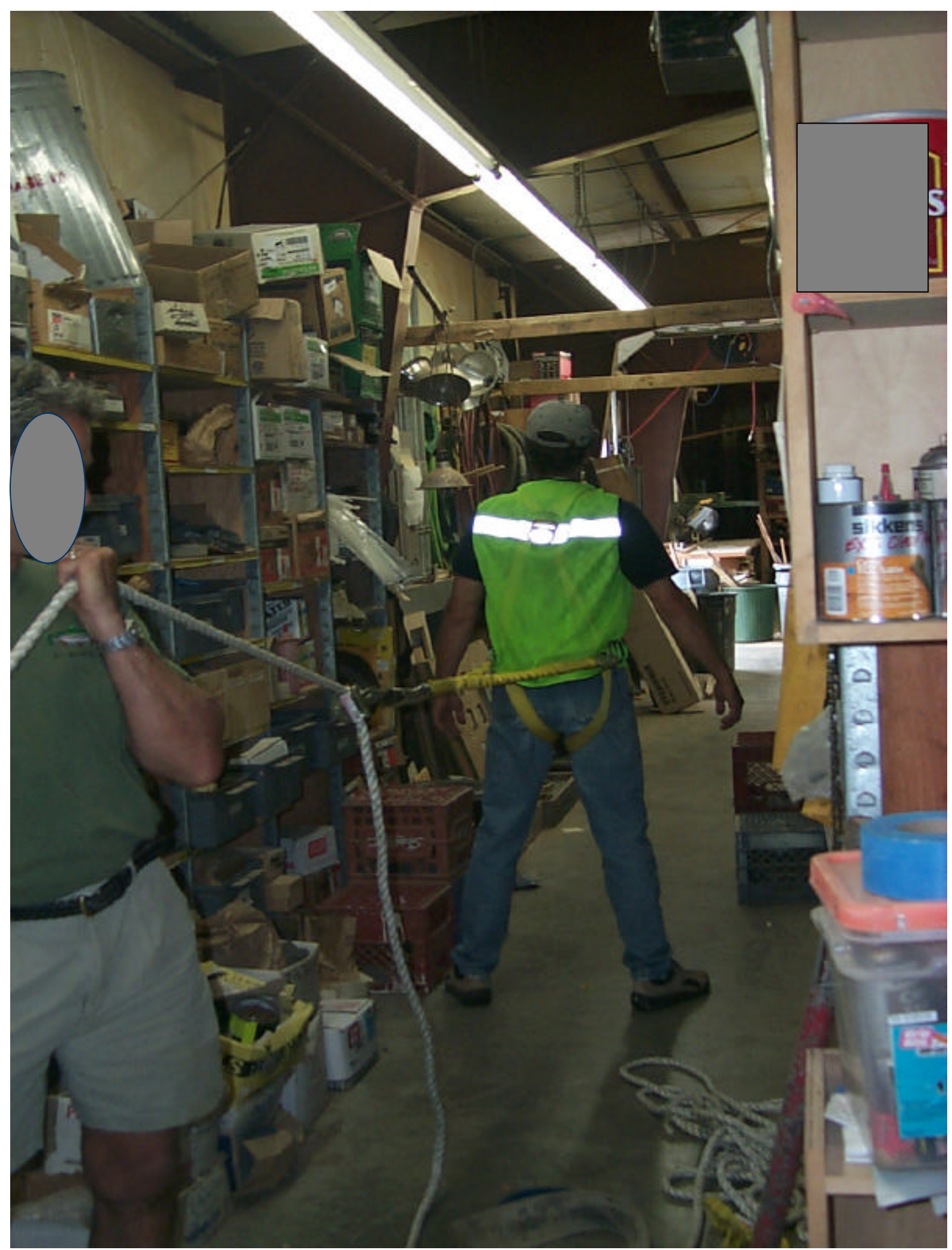

Picture of back of harness with lanyard attached. 


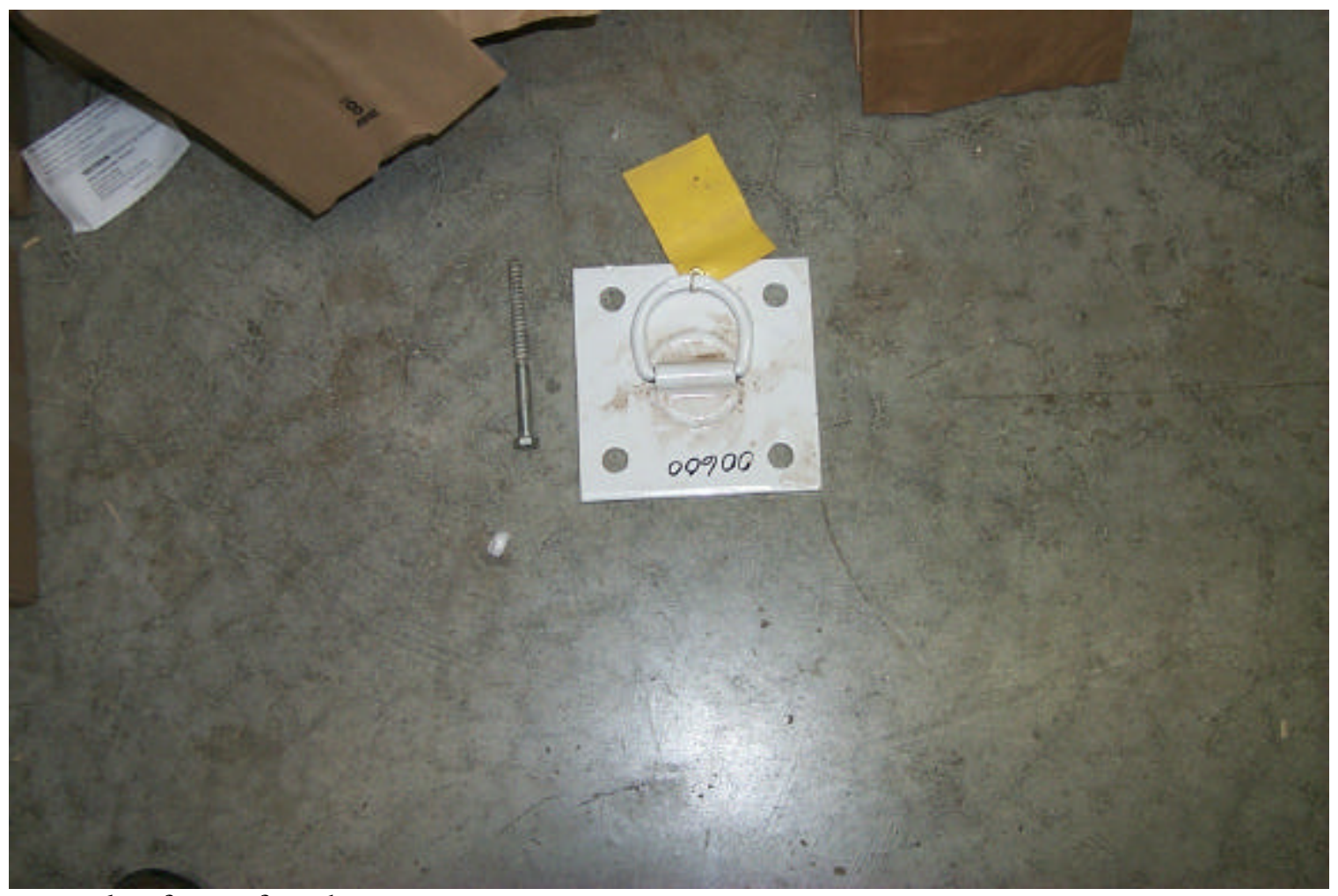

An example of a roof anchor.

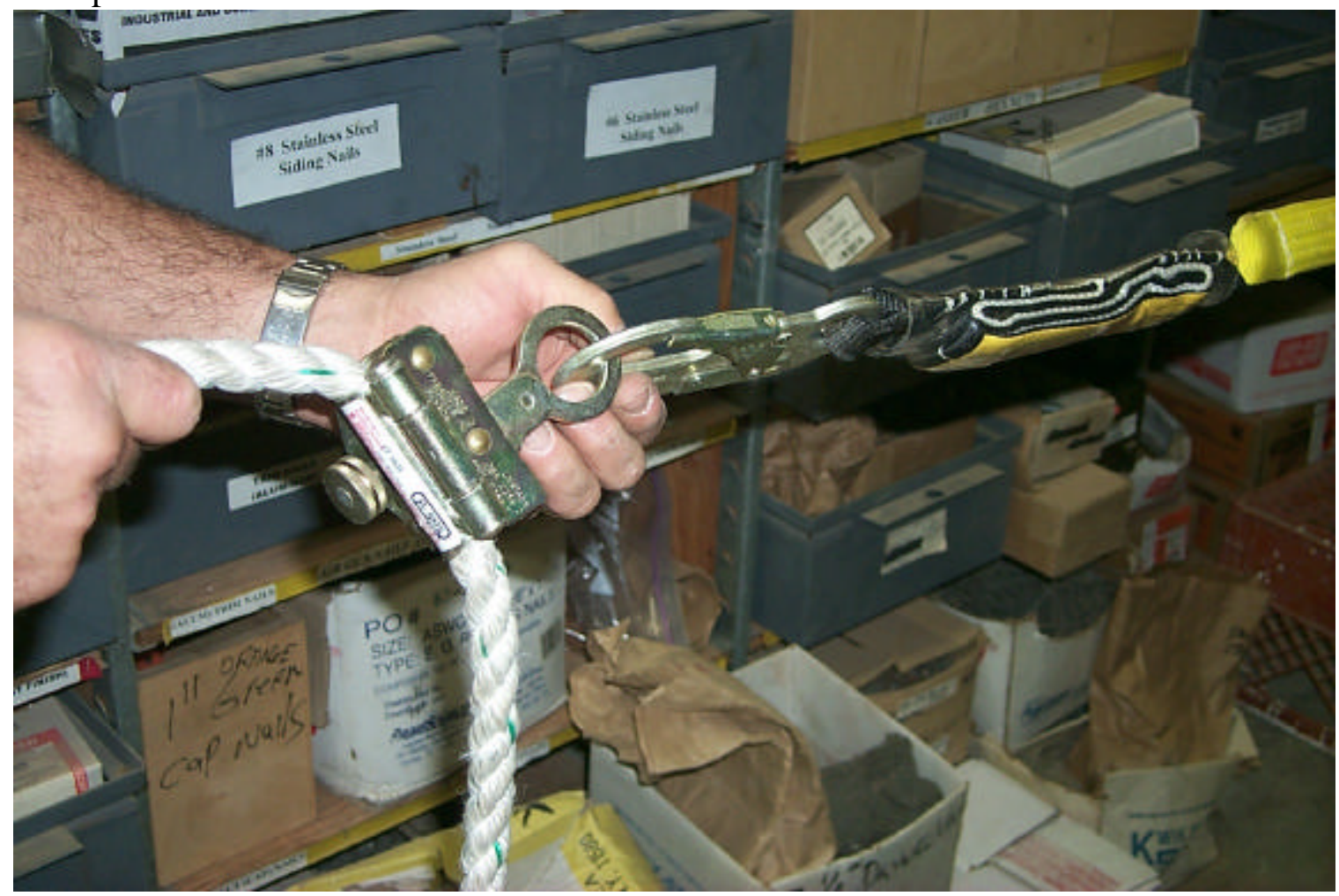

Picture of how lanyard is assembled to safety vest. 


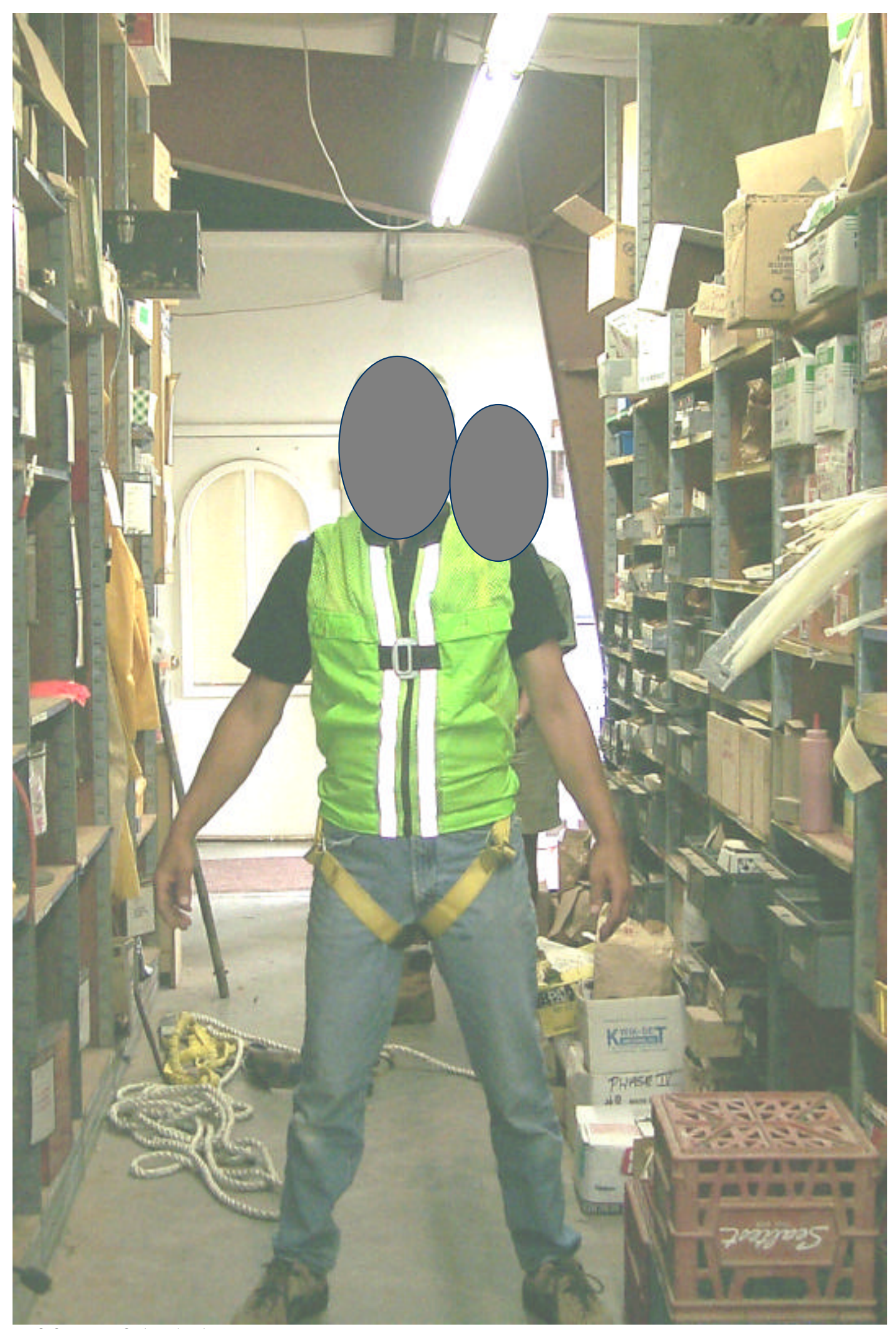

Picture of front of body harness. 


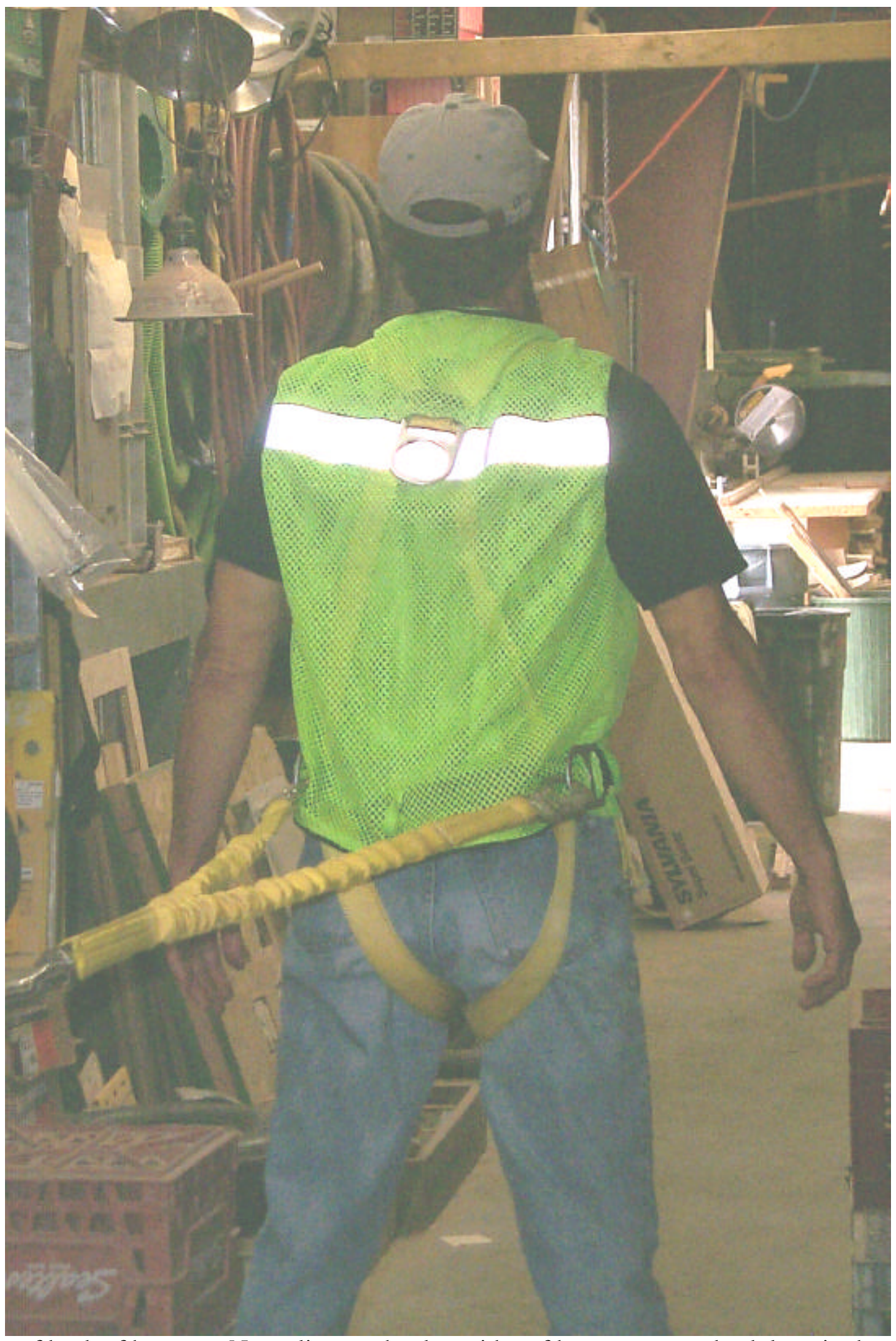

Picture of back of harness. Note clips can hook to sides of harness or to a back loop in the vest. 